just as outstanding. From his position at M.I.T. (1942-57) he moved to Yale University (1957-67) and then back to Harvard (1967-85). In 1977-87 he directed the International Institute for Comparative Political Research, Science Center Berlin. He presided over the American Political Science Association during the turbulent year 1969-70, and the International Political Science Association during years of expanding Third World membership and a world congress in Moscow (1976-79). Besides a half dozen honorary degrees, he received Germany's highest honor, Grand Cross of Merit.

Above all, Deutsch's students, his many scientific colleagues, and those who met him casually will doubtless remember best a sprightly mien and a brilliant mind tempered by a strong sense of humanity and fairness. $\mathrm{He}$ brought sparks to any lecture or private discussion: One had to work hard not to find something new and exciting. Moreover, he was eager to listen to any who had something interesting to tell him, to share his gifts with any who would pay heed. By the same token those insecure in their thoughts and excessively concerned about their status sometimes found him overwhelming. But those he touched personally or professionally-and they are legion not only in the United States but around the world-are glad that Karl came our way.

Richard L. Merritt

University of Illinois at UrbanaChampaign

\section{Charles B. Hagan}

Charles B. Hagan died on October 12,1991 in Houston, Texas at the age of 87 . He was a member and former chair of the department of political science at the University of Illinois from 1935 until his retirement in 1967. He then taught for eight years at the University of Houston.

Charles combined publications and service to the profession with an unfailing courtesy and commitment to standards of fairness in the education, hiring, and promotion of women and blacks long before that commitment was fashionable. As chair of the department of political science at the University of Illinois, he hired the first woman to ever teach in that department and lined up her first presentation at an APSA meeting (Betty Glad, one of the contributors to this memoir). He sought out black and minority graduate students and encouraged them; and he was unfailingly helpful to younger colleagues. On one occasion, he went looking at apartments with a graduate student from the Indian subcontinent. It was Charles' way of assuring the landladies of East Champaign that they could not turn the young man away on the basis of his color.

Another contributor to this memoir (Murray Edelman) was Charles' student before becoming his colleague, and like many others, remains his student still. In addition to subject matter, Charles' students learned that politics is a natural part of daily activity.

In addition to his years at Illinois and at the University of Houston, Charles Hagan taught at Emory and Henry College, Smith College, Harvard University, Duke University, and served in the U.S. Department of State. He received his Ph.D. from Duke University, was a Carnegie Fellow in International Law at Harvard University, and a Fulbright Fellow at the University of Sydney in Australia. Within the APSA, he served as a member of the Council, the Editorial Board of the APSR, and the Executive Committee, among others. His scholarship was wide ranging in the area of economic policy and legislative voting. Publications included Blueprint for Our Economic Democracy (co-written with Neil F. Garvey), three chapters in American Government and Economy by Emmette S. Redford, and the article "Geopolitics," which appeared in the Journal of Politics (November, 1942).

In the early 1950 s he was a pioneer in the movement to establish the influence of Arthur Bentley and group theory in political science. Because of his efforts the University of Illinois became a leading center of that movement.

Together with Mulford Sibley, Charles established a lively chapter of the Socialist Party in Urbana in the late 1940s and even became its candidate for City Council, enjoying the campaign though he failed to gain office.

He married Dorothy Veinus, who had been his colleague at Smith College. She was a good friend of many of his colleagues, a witty conversationalist and an outstanding musicologist. Dorothy died in 1980.

Charles is survived by a daughter, Patricia Kuwayama, and a son, John Lee Hagan. Other survivors are his sister, Rozelle Hagey of Bristol, Tennessee, and four grandsons.

Betty Glad

University of South Carolina

Murray Edelman

University of Wisconsin-Madison

\section{Thomas Ralph Solomon}

Thomas Ralph Solomon, professor emeritus of political science at Prairie View A\&M University, died on September 28, 1991 at the age of 87 in Houston, Texas. He was born March 18, 1904 in Macon, Georgia and attended private and public schools there, graduating as salutatorian from Ballard Normal High School on May 30, 1923.

He started his college education at Talladega College in Alabama where he remained until he married and moved to Detroit, Michigan. In Detroit he attended the City College of Detroit (now Wayne State University), receiving his A.B. in 1929 and his Masters degree in 1933. He continued his education at the University of Michigan while working full time as a postal clerk in the Detroit Post Office. Because of the way in which he combined graduate study and work he became a kind of folk hero. For example, The Detroit News, June 17, 1939, states "For two years Solomon has worked 5 days a week as a clerk in the Roosevelt Park Annex of the Detroit Post Office. He worked Saturdays and Sundays so he would be able to attend classes on Tuesdays and Thursdays. . . . Solomon was a porter in a downtown Detroit hotel when he decided to go back to college. . . . He worked four hours in the early afternoon as a substitute postal clerk. He also worked from $11 \mathrm{pm}$ to $6 \mathrm{am}$ in 
a Detroit creamery. He wanted to go to school but he had to support his family. It was a struggle. . . "' Dr. Solomon's 209-page thesis was entitled "The Negro in Detroit Elections."

When Thomas R. Solomon received the Doctor of Philosophy in political science in 1939, he became only the second black American to receive the terminal degree in the field. The first was Ralph Bunche, Nobel Prize laureate and American Political Science Association president. While he could earn a salary at the Post Office equivalent to that available at a black college, he was committed to a career in higher education. Dr. Solomon joined the Prairie View faculty in 1939 and remained at the university until his retirement in 1972. During his tenure, he served as professor of history, political science and philosophy; registrar; football coach; dean of students; and campus coordinator for many programs. Among his most outstanding positions was chief of party for the university's contract with the International Cooperation Administration's Point 4 Program of economic and educational assistance to Liberia from 1955 to 1958 . In 1961, the Liberian government conferred upon him the award "Knight Commander of the Humane Order of African Redemption" in recognition of the work done there, especially the establishment of the Booker T. Washington Technical Institute in Kakata, an institution which greatly expanded opportunity for advanced technical vocational training in that nation.

A master teacher and scholar, Dr. Solomon taught major courses in political science and served as consultant to university officials, government agencies and community institutions and groups. Under his leadership the undergraduate program in political science was developed at Prairie View. Among his former students at Prairie View are several professors of political science at colleges and universities across the nation, as well as successful lawyers. Former political science faculty members at Prairie View found in Dr. Solomon a strong mentor and career development facilitator.

Professor Solomon served as a member of the City Council of the City of Prairie View. Early in his tenure at Prairie View he was active in voter registration drives and the effort to get a voting precinct in the university community. He also played a major role in getting Prairie View incorporated as a municipality.

A man of indefatigable energy he held leadership roles in religious, civic, educational and political organizations. Following the death of his first wife, Lottie Green, Dr. Solomon married Pearl E. Foreman, who died in 1985 . He is survived by two sons, Samuel of Phoenix, Arizona, and James of Detroit, Michigan; 14 grandchildren, and many relatives and friends. A son, Thomas R. Solomon, Jr., preceded him in death.

Jewel L. Prestage

Prairie View A\&M University

\section{Jean G. Walen}

Jean G. Walen, who served in a range of administrative positions at the American Political Science Association from 1957 to 1991 when illness caused her retirement, died at her home in Rockville, Maryland, on November 5, 1992. Jean was born in Dufer, Oregon, and was a graduate of the University of Oregon. Before moving to Washington in 1955 , she was a reporter for the Eugene [Ore.] Register-Guard for two years. She is survived by her son, Michael, her mother, Annie Godknecht, and two sisters.

At the association, Jean worked with great dedication and skill on many programs and activities, including the Congressional Fellowship Program, annual meeting program coordination, the public affairs reporting awards, the annual dissertation list compilation, professional programs to enhance AfricanAmerican participation in the profession, professional awards, association directories, nominating committees, and she was administrative assistant to two executive directors, Evron M. Kirkpatrick and Thomas E. Mann. She also worked on projects that gave her special enjoyment, such as collecting material on former association presidents, assisting in the development of the Pendleton Herring collection of political art at the association headquarters, and compiling and publishing in $P S$ the list of the association's long-time members by years of membership.

At the memorial service for Jean, messages were read from a number of distinguished association members, including Pendleton Herring, Charles $\mathrm{O}$. Jones, Ruth Jones and Warren Miller, Jack Peltason, Nelson W. Polsby, Lucian W. Pye, and Austin Ranney. These communications attested to her long and excellent service and the view that Jean had served as the institutional memory of the association, which helped it to grow and to maintain the loyalty, respect, and support of its members.

Jean Walen was an institution builder, and the American Political Science Association is stronger for her work and life.

Walter E. Beach

Helen Dwight Reid Educational. Foundation 